\title{
THIRTY-FIRST STATED MEETING OF THE AMERICAN ORNITHOLOGISTS' UNION.
}

The Thirty-first Stated Meeting of the American Ornithologists' Union convened in New York City, Monday evening, November 10th, 1913. The business meeting was held at the Explorers' Club, 345 Amsterdam Avenue, and the public sessions, commencing Tuesday, November 11th, and lasting three days, were held at the American Museum of Natural History.

Business Session. The meeting was called to order by the President, Dr. Frank M. Chapman. Twenty-seven Fellows were present. The Secretary's report gave the membership of the Union at the opening of the present Stated Meeting as 992, constituted as follows: Fellows, 49; Retired Fellows, 2; Honorary Fellows, 15; Corresponding Fellows, 57; Members, 77; Associates, 792.

During the year the Union lost seventy-eight members, fourteen by death, twenty-nine by resignation, and thirty-five for nonpayment of dues. The deceased members include two Honorary Fellows, one Corresponding Fellow, one Member, and ten Associates, as follows:

Dr. Philip Lutley Sclater, one of the original Honorary Fellows, who died June 27th, 1913, at the age of 83 years; ${ }^{1}$ Prof. Alfred Russel Wallace, an original Honorary Fellow, who died in London, November 7 th, $1913,{ }^{2}$ in his 91 st year; Prof. Robert Collett, a Corresponding Fellow, who died at Christiana, Norway, January 27th, 1913, in his 71st year; ${ }^{3}$ Herbert Brown, a Member, who died

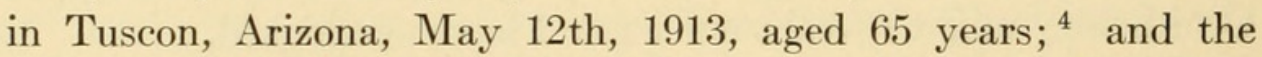
following Associates: Miss Louise Howe, who died September 13th, 1912; Mrs. Wm. H. Upham, who died November 29th, 1912; Chester A. Reed, who died at Worcester, Mass., December 16th, 1912, aged 36 years ${ }^{5}$; Mrs. Susan L. Davis, who died February

\footnotetext{
${ }^{1}$ For an obituary notice, see Auk, XXX, p, 621; also Memorial Address in the present number.

2 For an obituary notice see 'Notes and News' of this number.

${ }^{3}$ For an obituary notice, see Auk, XXX, p. 318.

4 For an obituary notice, see Auk, XXX, p. 472.

${ }^{5}$ For an obituary notice, see Auk, XXX, p. 319.
} 
13th, 1913; Florence A. Howe, who died July 1st, 1913; William H. Hill, who died October, 1913; Fred B. Spalding, who died at Lancaster, N. H., October 22d, $1913 ;{ }^{1}$ Jefferson Butler, who died in Detroit, Michigan, October 23d, 1913, aged 45 years; Henry Hales, who died November 6th, 1913; and Miss Lucy H. Baird, who died June 19th, 1913.

The report of the Treasurer showed the finances of the Union to be in a satisfactory condition.

All of the officers were re-elected as follows: Frank M. Chapman, President; A. K. Fisher and Henry W. Henshaw, Vice-Presidents; John H. Sage, Secretary; Jonathan Dwight, Jr., Treasurer; Ruthven Deane, William Dutcher, F. A. Lucas, Chas. W. Richmond, Thomas S. Roberts, Witmer Stone and Wilfred H. Osgood, members of the Council.

Waldo Lee McAtee, Washington, D. C., Joseph Mailliard, San Francisco, Cal., and Waldron De Witt Miller, of New York City, were elected Fellows; Hon. Lionel Walter Rothschild, of Tring, England, was elected an Honorary Fellow; Sergius N. Alphéraky, St. Petersburg, Russia, and Edward Daniel Van Oort, of Leyden, Holland, were elected Corresponding Fellows; Dr. Arthur A. Allen, Ithaca, N. Y., Dr. Rudolph M. Anderson, New York City, Dr. W. H. Bergtold, Denver, Colo., W. Lee Chambers, Eagle Rock, Cal., and George Willet, Los Angeles, Cal., were elected to the class of Members, and the following one hundred and forty-two persons were elected Associates:

Carl E. Akeley, New York City.

Miss Mary Pierson Allen, Hackettstown, N. J.

John S. Ames, North Easton, Mass.

Mrs. S. Reed Anthony, Boston, Mass.

Dr. B. H. Bailey, Cedar Rapids, Iowa.

David Ball, New York City.

Edwin B. Bartram, Wayne, Pa.

George Batten, Jr., Montclair, N. J.

William M. Bartlett, Allston, Mass.

Rev. George Bennett, Iowa City, Iowa.

Mrs. F. T. Bicknell, Los Angeles, Calif.

Dr. Lyman Fisher Bigelow, Norwood, Mass.

Harry C. Bigglestone, Sioux City, Iowa.

Miss Cora Blackledge, Beaver, Pa.

Wesley W. Blair, Newtonville, Mass. 
Prof. Donaldson Bodine, Crawfordsville, Ind.

Thomas L. Bourne, Hamburg, N. Y.

James Higginson Bowditch, Boston, Mass.

G. S. Britten, Syracuse, N. Y.

Miss Martha W. Brooks, Petersham, Mass.

Mrs. Jonathan Brown, Jr., Boston, Mass.

Harold Child Bryant, Berkeley, Calif.

Thomas D. Burleigh, Pittsburg, Pa.

Miss Clara D. Campbell, Brookline, Mass.

H. W. Carriger, Oakland, Calif.

Clarence H. Clark, Lubec, Me.

H. Walton Clark, Fairport, Iowa.

Ethan Allen Cleasby, Portage, Wisc.

Miss Anna E. Cobb, Providence, R. I.

Herbert L. Coggins, San Francisco, Calif.

S. Bayard Colgate, Orange, N. J.

Frederic M. Crehore, Boston, Mass.

Miss Viola E. Crittenden, Beverly, Mass.

Delos E. Culver, Addingham, Pa.

Benjamin H. Currier, Boston, Mass.

J. H. Davenport, Houston, Texas.

R. H. Dean, St. Louis, Mo.

Daniel Whitman Deane, Fairhaven, Mass.

Miss Elizabeth Downhour, Indianapolis, Ind.

Rupert A. Emmons, Washington, D. C.

Richard Erkskine, Wenonah, N. J.

William Floyd, New York City.

John S. Folk, Suffolk, Va.

Nathaniel A. Francis, Brookline, Mass.

W. D. Funkhouser, Ithaca, N. Y.

Mrs. W. W. George, Parkersburg, W. Va.

Miss Elizabeth F. Gray, Dedham, Mass.

Miss Caroline S. Greene, Cambridge, Mass.

Gilbert Hovey Grosvenor, Washington, D. C.

Mrs. W. K. Harrington, New York City.

William S. Haskell, New York City.

Prof. Francis H. Herrick, Cleveland, Ohio.

Newbold Lawrence Herrick, Cedarhurst, N. Y.

Mrs. J. Emory Hoar, Brookline, Mass.

Paul Griswold Howes, Stamford, Conn.

Laurence M. Huey, San Diego, Calif.

Edwin D. Hull, Chicago, Ill.

Norman James, Baltimore, Md.

Miss Flora Amy Jarves, Kingston Hill, R. I.

Richard D. Jennings, East Orange, N. J.

J. M. Johnson, Brooklyn, N. Y. 
Henry Justice, Devon, Pa.

Ralph T. Kellogg, Silver City, New Mexico.

Duane E. Kent, Rutland, Vt.

Wilfred L. Kihn, Brooklyn, N. Y.

Prof. P. E. Kretzman, St. Paul, Minn.

Stanley Vaughan La Dow, New York City.

Charlotte E. Lee, New York City.

L. Alva Lewis, Portland, Oregon.

George Herbert Lings, South Nyack, N. Y.

Luther Little, 2d, Los Angeles, Calif.

Rubert J. Longstreet, De Land, Fla.

Miss Marion B. Loring, Dedham, Mass.

F. B. Lund, M. D., Boston, Mass.

Herschel James McCallum, Pittsburg, Pa.

Miss Harriette Frances McIntyre, Newton, Mass.

Hon. George Payne McLean, Simsbury, Conn.

Walt F. McMahon, Roxbury, Mass.

James C. Maples, Port Chester, N. Y.

Vinton W. Mason, Cambridge, Mass.

Luke B. Martin, Clearwater, Florida.

George Henry Mengel, Reading, Pa.

Dayton Eugene Merrill, State College, New Mexico.

Zeno Payne Metcalf, West Raleigh, N. C.

George Ralph Meyer, Fort McKinley, Me.

Miss Heloise Meyer, Lenox, Mass.

Leo Dwight Miner, Washington, D. C.

Horace H. Mitchell, Saskatchewan, Canada.

George M. Mischke, Brooklyn, N. Y.

Miss Julia Eleanor Moody, Wellesley, Mass.

Chas. S. Moore, San Diego, Calif.

Albert Sidney Morgan, Winfield, W. Va.

Miss Eliza A. Morse, Worcester, Mass.

Frederick S. Moseley, Boston, Mass.

James Alexander Munro, Okanagan Landing, B. C.

Mrs. Lucius Nims, Greenfield, Mass.

Gladwin Kingsley Noble, Yonkers, N. Y.

Geoffrey Maurice O'Connell, Ithaca, N. Y.

Horace C. Ohl, Los Banos, Calif.

Miss Elizabeth Irving Ordway, Winchester, Mass.

Azel A. Packard, Springfield, Mass.

Chas. A. Philhower, Chatham, N. J.

Mrs. Dan Fellows Platt, Engelwood, N. J.

E. F. Pope., Colmesniel, Texas.

Mrs. S. W. Powell, West Becket, Mass.

Ligon Price, Dumnore, W. Va.

Wilson Blaine Rector, Belington, W. Va. 
Miss Mary Henrietta Renshaw, New Orleans, La.

Ward Jennings Rice, Roachdale, Ind.

Mrs. C. G. Richards, Lancaster, Pa.

Walton Ricketson, New Bedford, Mass.

James O. Roberts, Utica, N. Y.

William Allen Robinson, Vineyard Haven, Mass.

Harold Goddard Rugg, Hanover, N. H.

Arlie William Schorger, Madison, Wisc.

William G. Scott, Winnipeg, Manitoba, Canada.

Louis Agassiz Shaw, Beverly Farms, Mass.

Arthur L. Souther, Stoneham, Mass.

Miss Ethel Downing Spears, New York, N. Y.

Delmar Charles Speenburgh, New York City.

Miss Mary T. Spooner, Boston, Mass.

E. Alfred Steck, Philadelphia, Pa.

George H. Stuart, Philadelphia, Pa.

Arthur W. Sugden, Hartford, Conn.

S. S. S. Stansell, Manly, Alberta.

George Cushman Stearns, Dedham, Mass.

Herman Foster Stone, Lawrence, N. Y.

Lionel Edward Taylor, Bankhead Ranche, Kelowna, B. C.

Albert Joseph Tourtellotte, Westboro, Mass.

William Henry Triscot, Sonora, Sutton Co., Texas.

William Y. Wadleigh, Boston, Mass.

Frederic Collin Walcott, New York City.

Alexander Walker, Mulino, Oregon.

Chas. R. Wallace, Delaware, Ohio.

Willis G. Warner, Canfield, Ohio.

Francis M. Weston, Jr., Charleston, S. C.

D. V. Wharrum, Anstinburg, Ohio.

Dr. James C. White, Boston, Mass.

Miss Helen Willard, Brookline, Mass.

Miss Mary Alice Willcox, Ph. D., Malden, Mass.

DeWitt C. Wing, Chicago, Ill.

Wallace Park Young, Toronto, Canada.

Dr. A. K. Fisher, E. W. Nelson and Dr. Chas. W. Richmond were re-appointed 'Committee on Bird Protection.'

Public Sessions. First Day. The meeting was called to order by the President, Dr. Chapman. An address of welcome was made by Prof. Henry Fairchild Osborn on behalf of the President, Trustees and Scientific Staff of the American Museum of Natural History.

The papers read during the morning session were as follows: 
'A Study of the Feeding of Nestlings,' by Prof. Lynds Jones. Remarks followed by Dr. Merriam and Mr. Batchelder.

'The Work of a Village Bird Club,' by Ernest Harold Baynes. Illustrated by lantern slides. Remarks followed by Messrs. Bowdish, Saunders, Bond, Fuertes, Seton, Lord and Smith, Miss Moore, and Drs. Bishop, Fisher and Merriam.

'Experiments in Feeding Hummingbirds during Seven Summers,' by Miss Althea R. Sherman.

'A Plea for the Conservation of the Eider,' by Dr. Chas. W. Townsend. Remarks followed by Messrs. Arnold, Cleaves, and Bent.

It was voted to send copies of Dr. Townsend's paper to the Governor General of Newfoundland, and the Lieutenant Governor of the Province of Quebec, with the recommendation that proper measures be taken for the protection of the Eider on the Labrador Coast, thus preventing its extinction.

'In Memoriam - Philip Lutley Sclater,' by Dr. Daniel Giraud Elliot.

The following papers, all illustrated by lantern slides, were presented at the afternoon session.

'The Problem of Gliding Gulls,' by William Palmer. Remarks followed by Messrs. Bond, Saunders, Forbush, and the author.

'Some Observations on the Nesting of the Pied-billed Grebe,' by Dr. Arthur A. Allen. Remarks followed by Messrs. Seton and Job.

'Birds of the Bogota Region of Colombia,' by Dr. Frank M. Chapman.

In the evening an informal reception was held in the ornithological laboratories of the American Museum of Natural History, tendered to members of the A. O. U., by the Board of Trustees and Officers of the Museum.

Second Day. The meeting was called to order by President Chapman.

The papers of the morning session were:

'Some Migration Phenomena,' by Prof. Lynds Jones. Remarks followed by Messrs. Forbush, Saunders and Baily, and Dr. Arthur A. Allen.

'Bird Groups at the Field Museum of Natural History, Chicago, 
Ill., by Wilfred H. Osgood. Illustrated by lantern slides. Remarks followed by Dr. Palmer, Mr. Bent and the Chair.

'Persuading the Robins to Nest near Our Homes,' by Mrs. E. O. Marshall.

'Alexander Wilson, 1766-1813, and some Wilsoniana,' by Dr. Witmer Stone. Remarks followed by Messrs. Deane and Forbush.

'The Present Status of Wild Swans in Montana,' by E. S. Cameron. In the absence of the author it was read in part by A. C. Bent.

'A Forgotten Plumage Character of the American Scoter,' by Dr. Jonathan Dwight, Jr. Remarks followed by Messrs. Fuertes and Palmer, Miss Moore, and Dr. Stone.

'Bird Banding Activities; Season 1913,' by Howard H. Cleaves. Illustrated by lantern slides. Remarks followed by Messrs. Job and Fuertes, Dr. Palmer, and the author.

The following papers, all illustrated by lantern slides, were presented at the afternoon session:

'Wild Fowl Studies in Northern Manitoba,' by Herbert K. Job.

'The Musical Method versus the Syllabic Method of Recording Bird Songs,' by Robert Thomas Moore. Remarks followed by Messrs. Saunders, Coale, Murphy, Cleaves, and the Chair.

'Crossing the Andes of Peru,' by Wilfred H. Osgood.

In the evening the members of the Union, and their friends, met at dinner at the Hotel Endicott.

Third Day. The meeting was called to order by President Chapman. The papers of the session were:

'Some Ornithological Aspects of the Federal Migratory Bird Law,' by Dr. T. S. Palmer. Discussion followed by Wm. S. Haskell, Counsel of the American Game Protective Association, regarding the constitutionality of the bill.

'Bird Studies on James Bay,' by W. E. Clyde Todd.

'The Present Condition of the Aviary, of the New York Zoölogical Society,' by C. William Beebe.

'Birds of the South Atlantic,' by Robert Cushman Murphy. Illustrated by lantern slides.

The following papers, in the absence of their authors, were read by title:

'Notes on the Nesting Habits of the Northern Violet-green 
Swallow (Tachycineta thalassina lepida), at Seattle, Washington,' by S. F. Rathbun.

'Notes on Nighthawks,' by Harry C. Oberholser.

Resolutions were adopted thanking the President and Trustees of the American Museum of Natural History for a place of meeting, and for other courtesies tendered to the Union; to the Linnæan Society of New York for generous hospitalities extended to the Union during the Thirty-first Stated Meeting; to the Executive Committee of the New York Zoölogical Society for their polite invitation to visit the Zoölogical Park and the Aquarium of the Society; and to Robert W. Priest, of the Gaumont Co., Limited, of London, for his courtesy in allowing, a special exhibition at the Thursday afternoon session, of the motion pictures of antarctic life taken by Herbert G. Ponting, F. R. G. S., the official photographer of the late British Antarctic Expedition under Capt. Scott.

On Friday, November 14th, upon invitation of the New York Zoölogical Society, many members of the Union visited the Aquarium and the New York Zoölogical Park. They were received by Director Townsend and Curator Beebe and entertained at luncheon at the Park.

The registered attendance of members was unusually large, and the number of new members elected has been exceeded but once since the foundation of the Union.

The next meeting of the Union will be held in Washington, D. C., the date to be determined later. ${ }^{1}$

John H. SAge, Secretary.

${ }^{1}$ See 'Notes and News' of this number for date. 


\section{$2 \mathrm{BHL}$ Biodiversity Heritage Library}

Sage, John Hall. 1914. "Thirty-First Stated Meeting of the American

Ornithologists' Union." The Auk 31, 92-99. https://doi.org/10.2307/4071843.

View This Item Online: https://www.biodiversitylibrary.org/item/54326

DOI: https://doi.org/10.2307/4071843

Permalink: https://www.biodiversitylibrary.org/partpdf/86698

\section{Holding Institution}

Smithsonian Libraries

\section{Sponsored by}

Smithsonian

\section{Copyright \& Reuse}

Copyright Status: Public domain. The BHL considers that this work is no longer under copyright protection.

This document was created from content at the Biodiversity Heritage Library, the world's largest open access digital library for biodiversity literature and archives. Visit BHL at https://www.biodiversitylibrary.org. 